\title{
The Impact of Employee Satisfaction as a Mediator of Compensation and Career Development on Employee Performance
}

\author{
Kholilah*, Yukke Sartika Sari \\ *Universitas Muhammadiyah Palembang \\ Email : kholilah@um-palembang.ac.id, yukkesartikasari@um-palembang.ac.id
}

\begin{abstract}
The formulation of the problem in this study is 1) Is there any effect of compensation and career development on the satisfaction of PT. XYZ; 2) Is there any effect of compensation and career development on the performance of employees of PT. XYZ; 3) Is there an effect of satisfaction on the performance of the employees of PT. XYZ; 4) Is there any influence of compensation and career development on employee performance through the satisfaction of PT. XYZ. The research objectives are 1) To determine the effect of compensation and career development on the satisfaction of PT. XYZ 2) To determine the effect of compensation and career development on the performance of PT. XYZ employees; 3) To determine the effect of satisfaction on the performance of employees of PT. XYZ 4) To determine the effect of compensation and career development on employee performance through the satisfaction of PT. XYZ.

This type of research is associative research. The variables used are compensation, career development, satisfaction and employee performance. The sample used is 70 people with the sampling technique using probability sampling. The data used in this study are primary data collected through questionnaires. The data analysis technique used is Path Analysis.

The results show that 1) there is a significant effect of compensation on satisfaction and there is no influence on career development on satisfaction 2) there is a significant effect of compensation and career development on employee performance 3) there is a significant effect of satisfaction on employee performance 4) there is a significant effect on compensation and career development about employee performance through satisfaction.
\end{abstract}

\section{Keywords: Compensation, Career Development, Employee Satisfaction and Performance}

\section{Citation}

Kholilah., \& Sari, Y.S. (2021). The impact of employee satisfaction as a mediator of compensation and career development on employee performance. International Journal of Business, Management and Economic Research, 2(1), 31-43. 


\section{Introduction}

The role of employees is very important to the success or failure of the company. Companies in this case need to monitor the performance of each employee whether they have carried out their duties and obligations as expected. This job appraisal is very important to determine whether the company will continue to work with employees if their performance is good, or vice versa if the employee's performance does not match expectations.

Employee performance refers to the ability of employees to carry out all the tasks they are responsible for (Murty and Hudiwinarsih, 2012). To provide similarity in performance, the company must establish standard and standard measurements so that it can be used as a guideline by each employee (Damayanti, Susilaningsih, dan Sumaryati, 2013). Efforts to improve employee performance, including by paying attention to compensation and career development and employee job satisfaction.

Compensation attracts employees' attention and provides information or reminds about the importance of something that is compensated compared to others, compensation also increases employee motivation towards performance measures, thereby helping employees allocate employee time and effort. Compensation given to employees also greatly affects the level of job satisfaction and work motivation, as well as work results (Mangkunegara, 2008: 28). It is not only compensation that affects employee performance but career development as well.

With the assumption that human resources are a valuable asset for the company, each company must develop the potential of its employees and be responsible for improving the welfare of employees through career development. Human resources must always be developed if the organization wants to exist in the business world which is always changing.

The object of this research is PT. XYZ. This company is engaged in the contractor sector in the field of services such as building construction, civil buildings. Mechanical and electrical installations, and other implementation services. The potential of the construction service business plays a very important role in the field of suppliers, contractors and general trading which have an integrated operating, manufacturing and implementation system by procuring goods and general trading. However, the main business in this company is a contractor (contractor services). With the construction service industry, it will provide great opportunities for the absorption of workers who have expertise in the construction and building services industry. With the availability of jobs, it will create income for the workforce and reduce the unemployment rate.

\section{Literature Review}

\subsection{Previous Research}

Shintia's (2020) research in his research entitled the effect of compensation and work commitment on employee performance at PT. Pandawa Karya Palembang. Data analysis using 
multiple linear regression analysis. The results of the analysis show that partially compensation and work commitment have a positive and significant effect on employee performance at PT. Pandawa Karya Palembang.

Mawarni (2020) in his research entitled the influence of competence, compensation on work motivation, the impact on employee performance at PT. Somaery Citra Abadi in Palembang. The data analysis used is path analysis. The results of the analysis show that partial compensation has a direct effect on employee performance.

Dito (2010) in his research entitled the effect of compensation on the performance of employees of PT Slamet Langgeng Purbalingga with work motivation as an intervening variable. The analysis used is path analysis. The results of the analysis show that direct compensation has a positive and significant effect on employee performance.

\subsection{Employee Performance}

According to Wibowo (2016) performance is a process of how work takes place to achieve work results. In addition, Afandi (2018) states that performance is the result of work that can be achieved by a person or group of people in a company in accordance with their respective authorities and responsibilities in an effort to achieve company goals illegally, does not violate the law and is against morals and ethics. .

\subsection{Employee satisfaction}

According to Wijono (2012) satisfaction is a pleasant feeling which is the result of individual perceptions in completing tasks or fulfilling their needs to obtain work values that are important to themselves. Meanwhile, according to Afandi (2018) satisfaction is an effectiveness or emotional response to employees of various aspects of work.

Several factors can affect employee satisfaction, namely the job itself, salary, promotion opportunities, relationships with superiors, and coworkers (Afandi, 2018).

\subsection{Compensation}

According to Wibowo (2016) compensation is the number of packages that the organization offers to workers in return for using its labor. Meanwhile, according to Hasibuan (2016) compensation is all income in the form of money, direct or indirect goods received by employees in return for services provided to the company.

\subsection{Career Development}

According to Hasibuan (2016) development is an effort to improve the technical, theoretical, conceptual and moral abilities of employees according to the needs of the job or position through education and training. Meanwhile, Nawawi (2005) states that career development is a series of positions or positions occupied by a person during a certain lifetime. 


\section{Research Method}

This type of research is research, where according to Sugiyono (2013) that associative research is research that aims to determine the effect or relationship between two or more variables. This research has the highest level compared to descriptive and comparative because this research can build a theory that can function to explain, predict and control a symptom. This research was conducted at the branch office of PT. XYZ Muara Enim, South Sumatra.

The variables used in the study consisted of:

a. Employee performance, in this study the employee's performance refers to the management of creating relationships and ensuring effective communication, with indicators consisting of goals and commitments.

b. Job satisfaction, in this study the satisfaction in question is a pleasant feeling which is the result of employees' perceptions of completing tasks, with indicators consisting of the work itself and colleagues.

c. Compensation, in this study the satisfaction referred to is the percentage of users of labor or services that have been provided by the workforce, with indicators consisting of salaries and incentives.

d. Career development, in this research, what is meant by career development is a series (sequence) of positions or positions occupied by a person during a certain lifetime.

The data collection used is a questionnaire. According to Sugiyono (2013) a questionnaire is a data collection technique carried out by a researcher by providing a sheet containing written questions to be answered by the respondent. Before the questionnaire was distributed to the respondents, the instrument was tested using the validity test of the contents of the statement. This is in line with Fauzi, Dencik, dan Asiati's (2019) statement that to measure the validity of the instrument, an item validity test was carried out. In addition, data reliability testing was conducted. Fauzi, Dencik, dan Asiati's (2019states that relevance is the extent to which a measurement can be trusted. To test the reliability of the data, the Cronbach Alpha statistical test was used. A construct is said to be reliable if the Cronbach Alpha value is greater than 0.60. If Cronbach Alpha approaches one, the reliability of the data will be more reliable (Ghozali, 2013).

The hypothesis proposed in this study is:

There is an effect of compensation and career development on employee performance with satisfaction as a mediating variable.

To test the hypothesis proposed above, testing using Path Analysis is carried out.

\section{Findings and Discussions}

\subsection{Test of Validity}

The results of validity testing can be seen in table 1 below. 
Table 1. Results of testing the validity of the research instrument

\begin{tabular}{|c|c|c|c|}
\hline Variable & $R$ value & Rtable & Specification \\
\hline \multirow[t]{5}{*}{ Compensation } & 0.724 & 0.3061 & valid \\
\hline & 0,559 & 0.3061 & valid \\
\hline & 0,544 & 0.3061 & valid \\
\hline & 0.709 & 0.3061 & valid \\
\hline & 0.663 & 0.3061 & valid \\
\hline \multirow[t]{5}{*}{ Career Development } & 0.681 & 0.3061 & Valid \\
\hline & 0.737 & 0,3061 & Valid \\
\hline & 0.661 & 0.3061 & Valid \\
\hline & 0.809 & 0.3061 & Valid \\
\hline & 0.670 & 0.3061 & Valid \\
\hline \multirow[t]{5}{*}{ Satisfaction } & 0.598 & 0.3061 & Valid \\
\hline & 0.705 & 0.3061 & Valid \\
\hline & 0.530 & 0.3061 & Valid \\
\hline & 0.517 & 0.3061 & Valid \\
\hline & 0.750 & 0.3061 & Valid \\
\hline \multirow[t]{5}{*}{ Employee performance } & 0.538 & 0.3061 & valid \\
\hline & 0.590 & 0.3061 & Valid \\
\hline & 0.753 & 0.3061 & Valid \\
\hline & 0.641 & 0.3061 & Valid \\
\hline & 0.711 & 0.3061 & Valid \\
\hline
\end{tabular}

Based on calculations in the table above, it shows that all variables that have a value of $r$ count is greater than the value of $r$ table ( $N=30$ with a significant level of $10 \%$ is 0.3061 ). So it can be concluded that the variables of compensation, career development, satisfaction and employee performance used in this study are all categorized as valid so that they can be used in further data retrieval. 


\subsection{Reliability Test Reliability}

The results of testing can be seen in table 2 below.

Table 2.Results of research instrument reliability testing

\begin{tabular}{cccc}
\hline Variable & $\begin{array}{c}\text { Cronbach's } \\
\text { Alpha }\end{array}$ & $\begin{array}{c}\text { Minimum Cronbach's Alpha } \\
\text { required }\end{array}$ & Information \\
\hline Compensation & 0.634 & 0.60 & Reliable \\
Career Development & 0.756 & 0.60 & Reliable \\
Satisfaction & 0.600 & 0.60 & Reliable \\
Employee Performance & 0.616 & 0.60 & Reliable \\
\hline
\end{tabular}

Source: The results of the analysis using the SPSS application.

From the trials that have been carried out, it can be seen that the results of Cronbach's Alpha for each variable are more than the required minimum standard of Cronbach's Alpha, namely 0.60, then the variables of compensation, career development, job satisfaction and performance are reliable or have been good as a means of collecting. data.

\subsection{Data Analysis (Path Analysis)}

Sub Structural 1

Table 3. The results of the first sub-structural path analysis test

\begin{tabular}{|c|c|c|c|c|c|}
\hline \multirow{2}{*}{ Model } & \multicolumn{2}{|c|}{$\begin{array}{l}\text { Unstandardized } \\
\text { Coefficients }\end{array}$} & \multirow{2}{*}{$\begin{array}{c}\begin{array}{c}\text { Standardized } \\
\text { Coefficients }\end{array} \\
\text { Beta }\end{array}$} & \multirow[t]{2}{*}{$\mathbf{t}$} & \multirow{2}{*}{ Sig. } \\
\hline & B & Std.Error & & & \\
\hline (Constant) & 6,657 & 1,605 & & 4,147 & .000 \\
\hline Compensation & .481 & .093 & .571 & 5,188 & .000 \\
\hline Career Development & .118 & .093 & .141 & 1,278 & .206 \\
\hline
\end{tabular}

Source: The results of the analysis using the SPSS application.

Sub-structural equation model:

Published by:

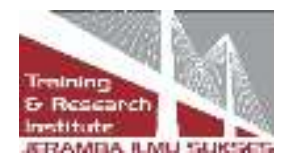


$\mathrm{Z}=\mathrm{B}_{1} \mathrm{X}_{1}+\mathrm{e}_{1}$

$\mathrm{Z}=\mathrm{B}_{2} \mathrm{X}_{1}+\mathrm{e}_{1}$

$\mathrm{Z}=0.571 \mathrm{X}_{1}+\mathrm{e}$

$\mathrm{Z}=0.141 \mathrm{X}_{2}+\mathrm{e}$

Due to Standardized Coefficients Compensation beta (X1) to satisfaction (Z) in this analysis is 0.571 the value of Standardized Coefficients Beta is the value of the path or path. With the value of Sig $=0.000 \geq 0.05$, it can be concluded that compensation has a positive effect on job satisfaction, meaning that there is a significant effect of compensation (X1) on satisfaction (Z). Because Standardized Coefficients Beta career development (X2) on satisfaction (Z) in This analysis is 0.141 the value of Standardized Coefficients Beta is the value of the path or path. With the value of Sig $=0.206 \leq 0.05$, it can be concluded that career development has no and insignificant effect on job satisfaction.

Sub Structural 2

Table 4. The results of the second substructural path analysis

\begin{tabular}{lccccc}
\hline \multicolumn{1}{c}{ Model } & \multicolumn{2}{c}{$\begin{array}{c}\text { Unstandardized } \\
\text { Coefficients }\end{array}$} & $\begin{array}{c}\text { Standardized } \\
\text { Coefficients }\end{array}$ & t & Sig. \\
\cline { 2 - 5 } & $\mathbf{B}$ & Std. Error & Beta & & \\
\hline Constant & 2.204 & 2.252 & & .979 & .331 \\
Compensation & .323 & .137 & .306 & 2.351 & .022 \\
Career Development & .253 & .117 & .240 & 2.157 & .035 \\
Satisfaction & .308 & .153 & .246 & 2.014 & .048 \\
\hline
\end{tabular}

Source: The results of the analysis using the SPSS application.

Second sub-structural equation model:

$\mathrm{Y}=\mathrm{B}_{1} \mathrm{X}_{1}+\mathrm{e}$

$\mathrm{Y}=\mathrm{B}_{2} \mathrm{X}_{1}+\mathrm{e}$

$\mathrm{Y}=\mathrm{B}_{3} \mathrm{Z}+\mathrm{e}$ 
$\mathrm{Y}=\mathrm{B}_{1} \mathrm{X}_{1}+\mathrm{B}_{3}+\mathrm{Z}$

$\mathrm{Y}=\mathrm{B}_{2} \mathrm{X}_{1}+\mathrm{B}_{3}+\mathrm{Z}$

$\mathrm{Y}=0.306 \mathrm{X}_{1}+\mathrm{e}$

$\mathrm{Y}=0.240 \mathrm{X}_{2}+\mathrm{e}$

$\mathrm{Y}=0.240 \mathrm{Z}+\mathrm{e}$

$\mathrm{Y}=0.306 \mathrm{X}_{1}+0.246 \mathrm{Z}+\mathrm{e}$

$\mathrm{Y}=0.240 \mathrm{X}_{2}+0.246 \mathrm{Z}+\mathrm{e}$

Because Standardized Coefficients Beta compensation (X1) on employee performance (Y) in this analysis is 0.306 the value of Standardized Coefficients Beta is the value of the path or path. With the value of Sig $=0.22 \geq 0.05$, it can be concluded that compensation has a positive effect on employee performance, meaning that there is a significant effect of compensation (X1) on employee performance (Y). Therefore, the Standardized Coefficients Beta of career development (X2) on employee performance (Y) in this analysis is 0.240 , the value of Standardized Coefficients Beta is the value of the path or path. With the value of Sig $=0.035 \geq 0.05$, it can be concluded that career development has a positive effect on employee performance, meaning that there is a significant effect of career development (X2) on employee performance (Y). Therefore, Standardized Coefficients Beta satisfaction (Z) on employee performance (Y) in this analysis is 0.246 the value of Standardized Coefficients Beta is the value of the path or path. With the value of Sig $=0.048 \geq 0.05$, it can be concluded that job satisfaction has a positive effect on employee performance, meaning that there is a significant effect of satisfaction $(Z)$ on employee performance $(\mathrm{Y})$.

Based on equations (1) and (2), an analysis model is obtained. path as follows:

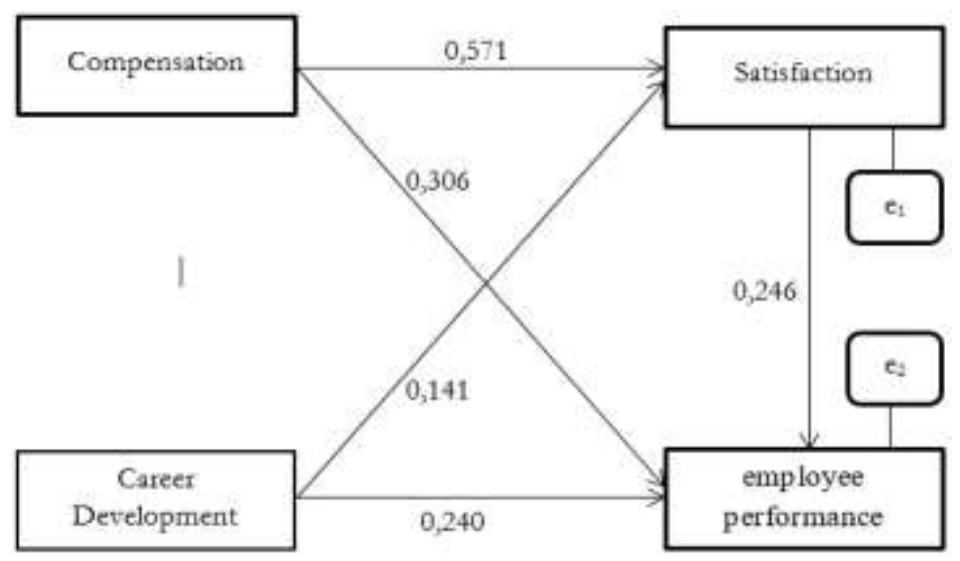

Figure 1. Full Structural Model Path Analysis 
Indirect Effect (IE)

Based on the results of the path analysis test with the following calculations:

1) The effect of the compensation variable on performance through satisfaction

$$
\mathrm{X} 1 \rightarrow \mathrm{Z} \rightarrow \mathrm{Y}=\left(\mathrm{B}_{1} \mathrm{X}_{1}\right) \times\left(\mathrm{B}_{3}\right)=(0.571 \times 0.246)=0.140
$$

The value of the indirect effect is obtained from the path coefficient value $\mathrm{B}_{1} \mathrm{X}_{1}$ multiplied by the path coefficient value $B_{3}$ becomes $(0.571 \times 0.246)=0.140$. So it can be concluded that these results indicate that there is an indirect effect between the compensation variable (X1) on employee performance (Y) through the satisfaction variable (Z).

2) Career development to Satisfaction to Employee Performance

$$
\mathrm{X} 2 \rightarrow \mathrm{Z} \rightarrow \mathrm{Y}=\left(\mathrm{B}_{2} \mathrm{X}_{1}\right) \times\left(\mathrm{B}_{3}\right)=(0.141 \times 0.246)=0.035
$$

The value of the indirect effect is obtained from the path coefficient value $\mathrm{B}_{2} \mathrm{X}_{1}$ multiplied by the path coefficient value $\mathrm{B}_{3}$ becomes $(0.141 \times 0.246)=0.035$. So it can be concluded that these results indicate that there is an indirect influence between the career development variable (X2) on satisfaction (Z) through the employee performance variable (Y).

The Direct, Indirect, and Total Effects

Conclusion of the value of direct, indirect, and total effects can be seen in the following table:

Table 5. Direct Effect, Indirect, and Total

\begin{tabular}{cccc}
\hline Variables & Direct Effect & Indirect Effect & Total Effect \\
\hline $\mathrm{Z} \leftarrow \mathrm{X} 1$ & 0.571 & - & 0.571 \\
$\mathrm{Z} \leftarrow \mathrm{X} 2$ & 0.141 & - & 0.141 \\
$\mathrm{Y} \leftarrow \mathrm{Z}$ & 0.246 & - & 0.246 \\
$\mathrm{Y} \leftarrow \mathrm{X} 1$ & 0.306 & 0.140 & 0.275 \\
$\mathrm{Y} \leftarrow \mathrm{X} 2$ & 0.240 & 0.035 & 0.446 \\
\hline
\end{tabular}

Compensation has an effect on employee job satisfaction with a significant and positive coefficient value. Compensation also contains a professional relationship where one of the main goals of employees to work is to get rewards to meet various needs, while on the company side 
they pay employees so that employees can carry out work in accordance with the wishes and expectations of the company with the main objective of being able to advance the company's business.

Hasibuan (2016) states that the purpose of providing compensation is, among other things, for employee job satisfaction which will later maintain the stability of the employees themselves so that they can reduce the turn-over rate. In addition, employees will also avoid the influence of labor unions and end up concentrating only on their work. This research supports research (Handoko \& Rambe, 2018) with the title "The Effect of Career Development and Compensation on Organizational Commitment through Job Satisfaction" with the result that compensation has a positive influence on Job Satisfaction. Therefore, it can be stated that compensation is one of the factors affecting job satisfaction at PT. XYZ.

Career development has no effect on employee job satisfaction with the coefficient value which is not significant and negative. These results do not agree with or do not support previous research, especially research from Tilaar's (2014) study. The study found that career development was proven to have an influence on employee job satisfaction, whereas in this study career development was not shown to have an effect on employee job satisfaction.

This indicates that career development is not one of the variables that influence or is not a predictor of job satisfaction and particularly job satisfaction of PT. XYZ employees. It was found that career development was not proven to have an effect on job satisfaction because for PT. $\mathrm{XYZ}$ employees this career development was not considered to be too related to job satisfaction levels. This is because career development at PT. XYZ in terms of achievement is not appreciated. This is what causes employees to be underdeveloped and career development to experience significant obstacles, especially the satisfaction level of PT. XYZ employees.

Compensation has an effect on employee performance with a significant and positive coefficient value. And the results of statistical calculations show a significance value of $0.035<0.05$, this means that the hypothesis which states that career development has a significant effect on the performance of PT. XYZ employees is accepted. Based on the statistical test, it can be explained that career development has an effect on employee performance with a significant and positive coefficient value.

Compensation has an effect on employee performance with a significant and positive coefficient value. This can be due to the indicator that the employee is satisfied with his current job is an important aspect in improving employee performance, the higher the job satisfaction felt by the employee, the employee's performance will increase or vice versa, the lower the job satisfaction, the lower the employee's performance.

Support provided by colleagues provides an opportunity to reduce pressure at work. The support provided by colleagues is related to the work done so that employees can feel comfortable at work so that they can improve the employee's own performance. This study supports the research (Mahesa, 2010) with the title "Analysis of the Influence of Motivation and Job Satisfaction on 
Employee Performance with Length of Work as a Moderating Variable" with the result that job satisfaction has a positive influence on employee performance. So thus it can be stated that satisfaction is one of the factors that affect the performance of employees at PT. XYZ.

From statistical calculations it can be concluded that there is a mediation effect, meaning that compensation and career development have a positive and significant effect on employee performance through job satisfaction, this indicates that the better the compensation and career development provided by PT. XYZ to employees, the more performance it will improve. employees through job satisfaction, so the fourth hypothesis which states that compensation and career development abilities have a positive and significant effect on employee performance through job satisfaction can be accepted.

\section{Conclusion}

Based on the analysis above, it can be concluded that there is an effect of compensation and career development on employee performance with satisfaction as the mediating variable. The most dominant variable in influencing employee performance is the compensation variable. So that to improve employee performance, compensation must also be increased. This is because good compensation can make employees feel enthusiastic about working.

\section{References}

Afandi, Pandi (2018). Manajemen Sumber Daya Manusia, Teori, Konsep, Indikator. Riau.

Damayanti, A. Puji., Susilaningsih., dan Sumaryati, Sri., (2013). Pengaruh Kompensasi dan Motivasi Kerja terhadap Kinerja Karyawan Perusahaan Daerah Air Minum (PDAM) Surakarta. Jupe UNS. Volume 2 (1) 155 - 168

Dito, A. Herdian. (2010). Pengaruh Kompensasi terhadap Kinerja Karyawan PT. Slamet Langgeng Purbalingga dengan Motivasi Kerja sebagai variabel intervening. Jurnal Fakultas Ekonomi Universitas Diponegoro, 41-42.

Fauzi, Fitriya., Dencik, AB., dan Asiati, D. Isnaini. (2019). Metodologi Penelitian untuk Manajemen dan Akuntansi. Salemba Empat. Jakarta

Ghozali, Imam. (2013). Aplikasi Analisis Multivariat dengan Program IBM SPSS. Edisi 7. Universitas Diponegoro. Semarang

Hasibuan, Malayu (2016). Manajemen Sumber Daya Manusia. Jakarta: Bumi Aksara.

Handoko, D. S., \& Rambe, M. F. (2018). Pengaruh Pengembangan Karir dan Kompensasi terhadap Komitmen Organisasi Melalui Kepuasan Kerja. Maneggio: Jurnal Ilmiah Magister Manajemen, 1(1), 31-45. 
Mangkunegara, Anwar Prabu. (2008). Manajemen Sumber Daya Manusia. Cetakan Kelima. Remaja Rosdakarya. Bandung

Mawarni, Gulo. (2020). Pengaruh Kompetensi, Kompensasi terhadap Motivasi Kerja Dampaknya pada Kinerja Karyawan di PT. Somaery Citra Abadi di Palembang. S-2 Thesis. Univesitas Tridinanti. Palembang

Murty, Windy Aprilia., dan Hudiwinarsih, Gunasti. (2012). Pengaruh Kompensasi, Motivasi, dan Komitmen Organisasional terhadap kinerja karyawan bagian akuntansi (studi pada perusahaan manufaktur di Surabaya). The Indonesian Accounting Review. 2 (2) 215 - 228

Nawawi, Hadari. (2005). Manajemen Sumber Daya manusia untuk Bisnis yang Kompetitif. Cetakan keempat. Gajah Mada University Press. Yogyakarta

Mahesa, Deewar. (2010). Analisis Pengaruh Motivasi Dan Kepuasan Kerja Terhadap Kinerja Karyawan Dengan Lama Kerja Sebagai Variabel Moderating.

Shitia, Afni. (2020). Pengaruh Kompensasi dan Komitmen Kerja terhadap Kinerja Karyawan di PT. Pandawa Karya Palembang. S-1 Thesis, Universitas Tridinanti. Palembang

Sugiyono. (2013). Metode Penelitian Kuantitatif, Kualitatif dan R\&B . Bandung : Alfabeta.

Tilaar, Ricky. 2014. Analisis Komitmen Organisasi, Pengembangan Karir dan Pemberdayaan Terhadap Kepuasan Kerja pada Kantor badan Pengelola Perbatasan Kepulauan Sangihe. Jurnal EMBA. 2 No.3 September. http://ejournal.unsrat.ac.id/index.php/emba. Diakses tanggal 4 Mei 2015. Hal. 991-1000.

Wijono, Sutarto (2012). Psikologi Industri dan Organisasi dalam Suatu Bidang Gerak Psikologi Sumber Daya Manusia, Edisi revisi. Jakarta.

Wibowo. (2016). Manajemen Kinerja. Edisi 5 Jakarta.

\section{Copyrights}

Copyright for this article is retained by the author (s), with first publication rights granted to the journal.

This is an open-access article distributed under the terms and conditions of the Creative Commons Attribution license (http://creativecommons.org/licenses/by/4.0/) 